\title{
Medical technologies and the life world: an introduction to the theme
}

\author{
Fredrik Svenaeus
}

Published online: 4 March 2009

(C) Springer Science+Business Media B.V. 2009

New medical technologies are increasingly transforming the meaning patterns of our everyday life. The new diagnostic and therapeutic possibilities that medicine offers transform and question borders between life and death, normality and abnormality, and health and illness, in direct and indirect ways. Technologies of assisted reproduction (IVF, PGD) are reshaping the forms of the beginning of life and the ability to choose what will happen in its course. Organ transplant techniques and life supporting technologies are making it possible to postpone death and be "born again" with new organs or mechanic devices. Genetics and stem cell research play major roles at both ends of life in promising the (future) knowledge and techniques of starting, predicting and prolonging life in various ways. Neurophysiology and psychiatry offer us ways of understanding and changing the self by aid of brain imaging techniques and pharmaceuticals already today.

Within the discipline of bioethics, philosophers are presently examining the ethical challenges which the new technologies will bring. This is important work: our ability to handle new technologies-and not let the technologies handle us-will be decisive for the society to come. However, in these epistemological and ethical analyses, life world issues are too rarely brought into play in any substantive way as new medical technologies are changing the patterns of our everyday lives in direct ways, and also reshaping our images of life, health, personality and the good life in a more indirect manner.

\section{F. Svenaeus $(\square)$}

Centre for Studies in Practical Knowledge,

Department of Philosophy, Södertörn University College,

14189 Huddinge, Sweden

e-mail: fredrik.svenaeus@sh.se
The contributions of this thematic block originate from a symposium held at Södertörn University in Sweden, November 2007. Out of the many papers presented at the symposium some were chosen to be elaborated and presented in this form after having been scrutinized in the customary peer review manner. The authors of these papers all work within the field of bioethics, but they do so with a considerable existential bend, which is inspired by the traditions of phenomenology and hermeneutics. They all address a question which you all too seldom find focused in contemporary bioethics: how do medical technologies intervene in the processes and possibilities, not only of selfenhancement, but also of self-formation. To be constituted as a self (person) is not only a matter of the physical and psychological capabilities you happen to be provided with by nature, or which you choose to promote or alter by way of medical technologies. It is basically a matter of choosing and editing your own identity within the meaning patterns of the life world. If these patterns are changed in fundamental ways-concerning borders between life and death, normality and abnormality, health and illness—it will have not only ethical, but also existential consequences for us.

This need not be a question of actually bringing about changes in, for instance, the human genome. It might just as much be a question of how new knowledge established by way of medical science alters our self-understanding. In the first contribution of this thematic section Hub Zwart (2009) analyses how genomics will change (and is already changing) the patterns of identity formation. Bioinformatics will be the principal pattern out of which future identity is shaped on an individual, as well as on a collective and genealogical, level. The information gathered by sequencing and analysing the DNA of each person, matching it for disease risks, behavioural tendencies, etc., will create possibilities not only in the domains of 
collective surveillance and public health, but also in the domains of individual life style choices and self understanding. To have "your self" stored on a memory stick is a powerful image for self narratives which raises many moral questions. Zwart compares the perspectives of two seemingly incompatible philosophers who have addressed the ethics of the genomic revolution: the "humanist" Francis Fukuyama, and the "post-humanist" Peter Sloterdijk. Diagnosing the flaws of genetic determinism, Zwart sides with Sloterdijk in emphasising that technology has been a major part of our "hominisation" ever since the start. Consequently there is no human essence to be lost by changing our unique human genome; what should be pointed out is that the effects of the new bioinformatics will be mostly indirect. We will not change our genes to the extent that "trans-humanists" (such as Nick Bostrom) believe and hope for, rather we will change our understanding of ourselves influenced by the new genetic information. This process contains many risks of misunderstandings and misuses of genetic information, on a societal as well as on an individual level, which we should analyse and deal with directly rather than making up stories of the new trans-humans to come.

The brain death criteria was adopted all over the world during the 1980s mainly as a consequence of the new possibilities of life supporting technologies and organ transplantation developed during the 1960s and 1970s. This is an extreme example of how medical technologies influence and redefine, not only matters of identity and normality, but actually the border between life and death. Had there not been an increasing demand for human organs kept fresh in human bodies while waiting to be transplanted to save the lives of others, death would probably still have been proclaimed the old way-not until the heart of the person ceased beating.

The heart death criteria did not fit with the new technologies of organ transplantation and life support and therefore it had to be changed. To not do so would, indeed, in the opinion of most people have been unethical. But how do we treat the persons who and groups which do not accept the brain death criteria? Does every individual and group have a right to not only their own death, but also their own death concept? Kristin Zeiler (2009) addresses this question in her contribution on global bioethics and proposes a critical, hermeneutical framework to incorporate the other as both the same and different from myself in solving ethical conflicts. Her examples are the New Jersey Death Definition Law and the Japanese Transplantation Law which both open the door to more than one concept of death within one and the same legal system.

If one were to mention influential books in the bioethical debate on new genetic technologies Jürgen Habermas' intervention Die Zukunft der menschlichen Natur - auf dem
Weg zu einer liberalen Eugenik? (2001) would probably end up somewhere close to the top of the list . Habermas' far from conclusive views have fuelled several attacks from philosophers and sociologists who have attempted to place Habermas in the conservative camp together with Leon Kass, Michael Sandel and others (e. g. Harris 2007, Rose 2007). The issue has mainly been with Habermas' claim that the child genetically designed by his own parents would be robbed of his autonomy and that this future scenario is fundamentally different from the way parents are presently shaping their child by way of environmental means. (For an excellent analysis of the moral concerns raised by the new possibilities of genetic enhancement of children to be, discussed by Habermas and others, see Erik Malmqvist: Good Parents, Better Babies: An Argument About Reproductive Technologies, Enhancement and Ethics (2008).)

Karin Christiansen highlights a theme in Habermas' book which has generally been overlooked; namely his use of Kierkegaard's reflections on the existential conditions for becoming oneself in works such as Either/or and The Sickness unto Death (Christiansen 2009). This existential concern of Habermas in fleshing out the distinction between (naturally) grown human traits and traits made (by way of genetic technologies) has been overshadowed in the bioethical debate by the focus on the issue if Habermas' diagnosis is empirically informed. Christiansen claims that the fault is really Habermas', since he fails to explain how the existential analysis at the beginning of his book is related to his succeeding reflections on the sociological and psychological impacts of genetic enhancement in the realm of communicative action.

Andrew Edgar (2009) also starts out within the framework of Habermas' book and contrasts Habermas' views to the ones of the "transhumanists" (a theme closely related to the approach of Hub Zwart in the contribution mentioned above). The existential theme is brought out in the contrasting stands Habermas and the transhumanists take on science and technology. Transhumanists, such as Nick Bostrom (2005), typically see the potential in genetic technologies for positively expanding and changing human nature. Habermas is a representative of those who are sceptical to genetic technologies, since they see the risk that the technologies will have deleterious effects on the founding meaning patterns of the life world by expanding the technological control and manipulation of humanity. The transhumanists remain confident that the life world has within it the resources necessary to find meaning and purpose in a society deeply infused by genetic technology. From the Habermasian position one would criticise such a view as being naïve and a representative of a Baconian faith in science as a project for the domination of nature (within ourselves) - a domination which will have fatal 
consequences for human self understanding and the possibilities of what Habermas calls a "species ethics".

The last contribution of this thematic section deals with the ethics of self-change from the perspective of the new antidepressants (Prozac). Fredrik Svenaeus (2009) argues that the massive rise in consumption of antidepressants in the last 20 years challenges basic assumptions of authentic self-change that are deeply ingrained in our Western culture: that changes in self should be brought about by laborious 'self-work' (psychotherapy) in which one explores the deep layers of the self (the unconscious) and comes to realise who one really is and should become. To become oneself has been held to presuppose such a psychic journey. He shows that while the assumed importance of self-work appears to be badly founded on closer inspection, the notions of exploring and knowing oneself appear to be more promising in fleshing out an ethical distinction between psychopharmacological and psychotherapeutic practice with the help of the concept of authenticity.

Looping, collective effects of psychopharmacological self-change in a cultural context are also considered by Svenaeus and this brings us right back to the life world. Temperament (mood) changes by way of medication have a looping structure that makes its outcomes even more dramatic. When certain aspects of our personalities are relabelled pathologies, the pressure to change these kinds of temperament styles increases. It will be even harder to feel at home with being melancholic or shy if the general message is that you should fix it by way of pills the way your neighbour or colleague at work has already done. Such medicalisation of life world issues-for good and for evil—is a permanent effect brought about by new medical technologies as they are incorporated in our culture and society. It has been the attempt of the authors of this thematic section to bring more light to this process by focusing directly upon the place and importance of the life world patterns in the medicalisation process. The hermeneutical challenges raised by new medical technologies in the areas of self-formation, ethics and politics are hopefully better addressed and answered through such a focus.

\section{References}

Bostrom, N. 2005. In defense of posthuman dignity. Bioethics 19: 202-214.

Christiansen, K. 2009. The silencing of Kierkegaard in Habermas' critique of genetic enhancement. Medicine, Health Care and Philosophy (this issue).

Edgar, A. 2009. The Hermeneutic challenge of genetic engineering: Habermas and the transhumanists. Medicine, Health Care and Philosophy (this issue).

Habermas, J. 2001. Die Zukunft der menschlichen Natur-Auf dem Weg zu einer liberalen Eugenik?. Frankfurt am Main: Suhrkamp Verlag.

Harris, J. 2007. Enhancing evolution-the ethical case of making better people. New Jersey: Princeton University Press.

Malmqvist, E. 2008. Good parents, better babies: An argument about reproductive technologies, enhancement and ethics. Linköping: Linköping Studies in Arts and Science No. 447.

Rose, N. 2007. The politics of life itself-biomedicine power, and subjectivity in the twenty-first century. Princeton: Princeton University Press.

Svenaeus, F. 2009. The ethics of self-change: Becoming oneself by way of antidepressants or psychotherapy?. Medicine, Health Care and Philosophy (this issue).

Zeiler, K. 2009. Self and other in global bioethics: Critical Hermeneutics and the example of different death concepts. Medicine, Health Care and Philosophy (this issue).

Zwart, H. 2009. Genomics and identity: The bioinformatisation of human life. Medicine, Health Care and Philosophy (this issue). 